\title{
Social acceptance being the prime reason of geographic differentiation in laws
}

\author{
Rafsan Mahaboob Chowdhury*
}

Abstract: The nexus between geography and law has been intertwined in different ways. Social phenomena are crucial factors for different laws across the world regarding an issue. The article tries to identify the geographical impact on various laws. It also focuses on to create a link between various societies, its cultures and how morality varies along with it. Furthermore it tries to create a link between the social acceptance of a law with morality as well as with geographical differentiation. The main focal point of this article is the reason of similar issues having different laws all over the world because of variations in culture, geography, norms etc. The article also tries to define social acceptance in a way that supports the article's claim in order to draw a conclusive analogy between the relation of social acceptance and geographic differentiation in laws.

\section{Keywords: Social Acceptance, Social desirability, Morality}

\section{Introduction}

It is not surprising that 'Law' is not universally definitive. ${ }^{1}$ Jurists and scholars have tried to define law in a lot possible angles, considering various influencing factors. Law is heavily dependent on two important aspects namely Morality and Social Acceptance. Morality varies dramatically depending on the geography. A moral law that is socially accepted in a nation-state might be criticized and be and offence in another. Two countries might have two different laws depending on the social environment and its level of acceptance towards a situation; i.e. an act might be an offence in a country but morally accepted in another and the law varies respectively because of its social mindset, acceptability and necessity. This paper looks into the society's behavior and its influence while recognizing a law in a

\footnotetext{
* LLB, University of London; BBA, Candidate, 2018 East Delta University; Lecturer, Faculty of law Newcastle Law Academy. Contact rafsan.chy1994@gmail.com.

${ }^{1}$ ANTONIN SCALIA \& AMY GUTMANN, A MATTER OF INTERPRETATION: FEDERAL COURTS AND THE LAW: AN ESSAY(Princeton Univ Press) (2017)
} 
wide perspective. The aim of the paper is to enlighten the social aspects of laws and morality.

\section{The Concepts of Law}

What is "Law"? The scholars, academicians or the theoreticians defined law as the body of official rules and regulations, generally found in constitutions, legislation, judicial opinions that are used to govern a society and to control the behavior of its members. ${ }^{2}$

Legal systems are particular ways of establishing and maintaining social order. For example, John Austin defined 'law' as 'A body of rules fixed and enforced by a sovereign political authority', ${ }^{3}$ Hart defined law as a 'system of rules, a union of primary and secondary rules', ${ }^{4}$ Greek philosopher Plato and Aristotle defined law as 'an embodiment of reason, whether in the individual or the community'.

Similarly, Hobbes said of the role and functions of law in his polemic work "Leviathan" (165l) and defined that "Law is the formal glue that holds fundamentally disorganized societies together'. ${ }^{6}$ Accordingly there are other views on the definition of 'law' as well. Holland's perception on law is that it is "a rule of external human action enforced by the sovereign political authority." According to Salmond, "Law is the body of principles recognized and applied by the State in the administration of justice." ${ }^{8}$ According to Woodrow Wilson, "Law is that portion of the established habit and thought of mankind which has gained distinct

\footnotetext{
${ }^{2}$ N. J. Schweitzer et al., Is the Rule of Law a Law of Rules? Judgments of Rule of Law Violations, SSRN ELECTRONIC JOURNAL(2009)

${ }^{3}$ JOHN AUSTIN, LECTURES ON JURISPRUDENCE, OR THE PHILOSOPHY OF POSITIVE LAW,(FORGOTTEN BOOKS) (2015)

${ }^{4}$ HeRBERT LiONEl AdOlPhUS HART ET AL., THE CONCEPT OF LAW(Clarendon Press) (2012)

5 JOHN LLOYD ACKRILL, ESSAYS ON PLATO AND ARISTOTLE(Oxford University Press) (2001)

${ }^{6}$ CHAMSY EL-OJEILI, POLITICS, SOCIAL THEORY, UTOPIA AND THE WORLD-SYSTEM: ARGUMENTS IN POLITICAL SOCIOLOGY(Palgrave Macmillan) (2012)

${ }^{7}$ E. VAN DEN HAAG, CRIME, PUNISHMENT, AND DETERRENCE(1977)

${ }^{8}$ Martin Partington, Law and society: the purposes and functions of law, LAW TROVE(2017)
} 
and formal recognition in the shape of uniform rules backed by the authority and power of the government."9

A lot of scholars also connected law with justice and mechanism for peaceful existence of society. Such as, according to Anson, "the objects of Law is Order, and the result of order is that men are enables to look ahead with some sort of security as to the future. Although human action cannot be reduced to the uniformities of nature, men endeavored to reproduce by Law something approaching to this uniformity."10 Similarly, according to Blackstone, "Law is a rule of civil conduct, prescribed by the supreme power of state, commanding what is right and prohibiting what is wrong."1l

Whatever or wherever the scholar's definition may differ, most of them have recognized three essential common characteristics of law. They are:

1. Law has its sovereign authority,

2. Law is accompanied by sanctions,

3. The command of law should compel a course of conduct.

In the modern world, morality and law are held to be disconnected fields and, where the expression "legal ethics" is utilized, it is taken to allude to the experts of legal counselors or judges, yet has nothing to do with the conceivable "rightness" or "wrongness" of specific laws themselves. "Law", according to the Encyclopedia Britannica, "refers to the specialized form of social control familiar in modern, secular, politically organized societies". The thomistic and christian view understands law otherwise: "it is nothing else than an ordinance of reason for the

\footnotetext{
${ }^{9}$ Anthony Bradney, Russell Sandberg: Religion, Law and Society, 42 JOURNAL OF LAW AND SOCIETY, 460-463 (2015)

${ }^{10}$ IREDELl Jenkins, Social ORder AND the Limits of LAW: A TheORETICAL EsSAY(Princeton University Press) (2014)

${ }^{11}$ Economic Arguments: Rent Theory and Property Rights Theory, URBAN LAND RENT, 46-62 (2015)
} 
common good, made by him who has care of the community, and promulgated."12 Without law, there is no society, only the jungle, and the rule of might "If there is justice, and if law is based on a discernment of what is just, dialogue can begin and benevolence can appear; so we come to what is ours in common. The first form of culture is law. Its effectiveness means that barbarism has been overcome: men have always been civilized this way"13

\section{Morality (a critical analysis)}

"Moral rules impose obligations and withdraw certain areas of conduct from the free option of the individual to do as he likes." ${ }^{14}$ Ethics or morals are the study of what we ought to do; i.e. what is the right way to act and what the wrong is. Fundamental moral concepts such as right and wrong are necessarily universal. The purpose of morality is to ensure the uprightness of individual conscience (the law cannot force a conscience to be upright). "The moralists were traditionally the representatives of the moral law, and their mission was to show to conscience how to apply it in a particular situation, in a "case of conscience". Today we witness a strong tendency to invert the roles; the moralists now regard themselves as defenders of freedom and of personal conscience" [as against the law $]^{15}$. If positivists point of view is considered Hobbes held that: "Auctoritas, non veritas facit legem" (Authority, not the truth, makes the law). ${ }^{16}$ This is reflected in the program for life which Goethe's Mephistopheles, the demon-spirit, proposes to men: "You have the Might (power), and so the Right"17

\footnotetext{
12 Thomas Aquinas: Summa Theologica I-II q. 90 a. 4).

${ }^{13}$ R. Yepes: Fundamentos de Antropología, Pamplona, 1996, p. 312

${ }^{14}$ HeRBERT LIONEL AdOlPhUS HART ET AL., THE CONCEPT OF LAW(Oxford University Press) (2012)

${ }^{15}$ Servais Pinckaers: Pour une Lecture de Veritatis Splendor, Paris, 1995, pp. 41-42.

${ }^{16}$ THOMAS HOBBES, LEVIATHAN: OR, THE MATTER, FORME, AND POWER OF A COMMON-WEALTH, ECCLESIASTICAL AND CIVIL(Printed for Andrew Crooke) (1651)

${ }^{17}$ FAUST PART 2 ACt 5 SCENE 3 POETRY IN TRANSLATION, https://www.poetryintranslation.com/PITBR/German/FaustIIActV.php (last visited Mar 3, 2018)
} 
A legal duty so called is nothing but a prediction that if a man does or omits certain things he will be made to suffer in this or that way by judgment of the court... The prophecies of what the courts will do in fact, and nothing more pretentious, are what I mean by the law... The duty to keep a contract at common law means a prediction that you must pay damages if you do not keep it - and nothing else"18. An apparently "democratic" version of this is that the authority of the law comes from the people: i.e. from the majority. But this still leaves minorities with no basis for any rights except those that the majority (or the manipulators of the majority) grants them. ${ }^{19}$ Pope John Paul II, in Evangelium Vitae (1995), says that in order to save true democracy and freedom, "there is a need to recover the basic elements of a vision of the relationship between civil law and moral law, which are put forward by the Church, but which are also part of the patrimony of the great juridical traditions of humanity" (no. 71). "There are some who assert that even if law and morals are distinguishable it remains true that morality is in some way an integral part of law or legal development."20 "Another approach would go much further and confer upon the legal process and inherent power to reject rules essentially non-legal ..., the present doctrine treats immoral rules as inadmissible rather than as being an external law of nature"21

"Law is also different from justice. Justice is a matter of the correct or best theory of moral and political right"22 Statutory or Parliamentary laws are rather a political tool that fits better in favour of the political parties compared to the public at large. Almost every statutory law has a political motive behind it. Human Rights Act

\footnotetext{
18 The Path of the Law (1897): quoted in R. George: The Clash of Orthodoxies, 212).

19 "The law is a great thing - because men are poor and weak, and bad. And it is great, because where it exists in its strength, no tyrant can be above it" (Anthony Trollope: The Duke's Children, Ch. 61).

${ }^{20}$ MiCHAEL FREEMAN, LLOYD'S INTRODUCTION TO JURISPRUDENCE (Sweet and Maxwell 8th) (2007)

${ }^{21}$ Michael FreEMAN, LLOYD'S INTRODUCTION TO JURISPRUDENCE (Sweet and Maxwell 8th) (2007)

${ }^{22}$ RoNALD DWORKIN, LAW'S EMPIRE (Fontana Press) (1986)
} 
1998, a standout amongst the most controversial statutes in the United Kingdom, was also a part of the election manifesto of Tony Blair in 1997 headed as "Rights brought home".

Sexual Offences Act 2003 as well in the UK was a formal statute that incorporated the decision of a leading case $R v R^{23}$ in the parliament. In $R v R$ the definition of rape was redefined by including marital rape which seemed to have been excluded by the Sexual Offenses (Amendment) Act 1976 by using the word "Unlawful" in its definition of Rape. The decision in $R v R$ was clearly moral but the purpose of enacting SOA 2003 was rather political. If the approach is seen differently, the decision of House of Lords in $R v R$ was not in accordance with the then standing statute that defined Rape during that time. It certainly meant parliamentary supremacy was hampered moreover the decision was made retrospectively.

If the decision was made relying on the statute the defendant wouldn't have been guilty of raping his wife as she was not an unlawful woman. Firstly the ulterior motive of enacting the statute was to retain sovereignty of the English parliament. Secondly, genuine people would lose confidence in the statutory laws but believe that courts provide justice. As the United Kingdom claims its parliament to be supreme, its statutes were supposed to be supreme as well. When the highest court of authority seemed reluctant in the rarest of instances and questions get raised, it is obvious that one who previously relied on a statute will no longer have faith in them and this could then be called for moral justifications.

Therefore, because of the ulterior motive complication anything other than judge made laws is not part of this research on social acceptability unless otherwise

\footnotetext{
${ }^{23}$ UNITED KINGDOM HOUSE OF LORDS DECISIONS R. V R [1991] UKHL 12 (23 October 1991),
} http://www.bailii.org/uk/cases/UKHL/1991/12.html (last visited Mar 7, 2018 
necessary. Morality of a person gets heavily affected by the way they were raised, social status, personalities of their family members, religion, culture, education, sociocultural environment and so on. A judge for instance is likely to be biased towards medical practicing defendants if the judge's father was a doctor. This might not always happen but none can deny that it sure is a possibility. On the other hand if a judge's father passed away for a doctor's negligence, and a case of tort committed under medical negligence comes up front, he is likely to have a "predecided judgement" in mind that the accused is guilty.

Although morality is claimed to be variable but in wider view it is constant. Cannibalism, rape, cold blooded murder, actual and grievous bodily harm with intention, piracy, and bribery are immoral irrespective of geography, race, and culture and so on. It has been observed that bribery has been newly termed as speed money. Speed money has also been legalized because of its acceptability in the society. For example to make a passport urgently it costs thrice the principle in Bangladesh. The speedy procedure ensures the passport is delivered in three days which would otherwise take 27 days. Does this not seem similar to a situation where a rich pays thrice the sum to a government official under the table to get the job done rapidly.

So morality seems to have changed hands and bribery became moral for the rich. As Marx said "it is not the consciousness of men that determines their being, but on the contrary their social being that determines their consciousness"24Therefore society demands such changes or specifically aligning with the example, paying more for an urgently made passport. This brings us to a very important research point, law being socially acceptable or a social requirement.

${ }^{24}$ KARL MARX, POVERTY OF PHILOSOPHY (ELECBOOK CLASSICS) (1847) 


\section{Morality and Social Acceptance}

If the passport example is considered to be moral then it should be argued that law is for the rich and religion is on the other hand for the poor because they do not have means to fight in the court and the expenses litigations bring with them is no secret. The poor can only hope the wrongdoers to be punished in the afterworld. However if we introduce social acceptability or desirability to define these, then all the controversies and contradictions can be ended. So what is meant by social acceptability? As Hart has described law to be a union of primary and secondary rules with the power to adjudicate a problem and to be able to change overtime along with the rules of recognition ${ }^{25}$, A plagiarized definition of law should stand that a law being socially acceptable would mean that a decision (be it parliamentary or courts') that adjudicates a problem by changing the standing principle because of societal need. This requires an explanation because of its vagueness.

As stated above it is clearly possible to define the aforesaid problems if social acceptability or desirability is introduced as part of law. The first problem with Human Rights act 1998 - the circumstances of the decisions of the House of Lords being challenged in Strasbourg i.e. in the European Court of Justice. It is understandable why this was happening happen back then taking the principles of $\operatorname{Van}$ Gend $N \operatorname{Loos}^{26}$ and SimmentheP7 into account. Because of the European

\footnotetext{
${ }^{25}$ Herbert Lionel Adolphus Hart et al., The Concept of law (Oxford University Press) (2012)

${ }^{26}$ VAN GEND \& LOOS, TITJUR, OPINION OF MR ADVOCATE GENERAL ROEMER DELIVERED ON 12 DECEMBER 1962. \# NV ALGEMENE TRANSPORT- EN EXPEDITIE ONDERNEMING VAN GEND \& LOOS V NETHERLANDS INLAND REVENUE ADMINISTRATION. \# REFERENCE FOR A PRELIMINARY RULING: TARIEFCOMMISSIE - NETHERLANDS. \# CASE 26-62. EU LAW AND PubliCATIONS, https://publications.europa.eu/en/publication-detail/-/publication/c17147ad-5a52-4280-a0ffa59466d0f3e0/language-en (last visited Mar 9, 2018)
} 
supremacy it was becoming difficult to rely on principles of the national courts of the member states which in this case would be the UK. So it can be said that the society desired a stable statutory development that would be able to eliminate this problem. HRA 1998 did not only provide a solution to this but also was able to upheld English parliamentary Sovereignty in a very beautiful yet controversial manner.

Subsequent to that, "speed money" problem could also be solved by the principle of social; acceptability. Previously when people were ready to pay the higher amount as a form of bribery to get the job done, it is wise to introduce some sort of extra payment for an added benefit. Because let's face it, the rich are privileged. Pay more to get a super deluxe suite, pay less to get a room probably even without an attached toilet. So same goes here as it is almost impossible to rub off the attitude towards bribery which is criticized yet accepted in countries like Bangladesh. It is better to be witty and implement such techniques because this is socially acceptable and more payment to get the job done fast is socially desired.

Law being retrospective is a matter of wide criticism all over the world. Although retrospective decisions can be easily justified by Dowrkin's Right answer thesis. He explains law to be a seamless web and judges try to find the solution which is presupposed to exist somewhere in the previous principles, judges's experience, legal knowledge of the judge or a combination of the above. ${ }^{28}$ Dworkin's objection to judicial originality is that "if a judge makes a new law and applies it retrospectively in the case before him, then the losing party will be punished, not because he has violated some duty he had, but rather a new duty was created after the event." If the citizen is being made retrospectively liable, it is because there

\footnotetext{
27 SUMMARY OF SIMMENTHAL - 106/77 OfFICIAL BLOG OF UNIO, https://officialblogofunio.com/2016/03/26/summary-ofsimmenthal-10677/ (last visited Mar 9, 2018)

${ }^{28}$ RONALD DWORKIN, LAW'S EMPIRE (Fontana Press) (1986)
} 
was no law at that time that could make him liable. This places a special duty upon the legislature to justify retrospective legislation. But let's look at this the other way around. Instead of using the term retrospective in the so called hard cases, introduction of the term social desirability seems much more suitable as well as accurate. So according to $R \boldsymbol{V} R$ the defendant could not be punished for committing marital rape because the alleged defendant back then was having forceful sexual intercourse with his lawful wife. And as stated above according to the 1976 definition of rape the woman must be unlawful (although many critics have given different definitions). But if we clearly say that the law was changed because of it being a social need to protect married women against predatory attacks $^{29}$. The question of injustice or moral harm being caused due to retrospective decisions can be overturned by the introduction of this very new area in legal jurisprudence.

\section{Laws' and geographic differentiation- a comparative view of social acceptance.}

Designated "a motto of our discipline" 30 by geographers, the first law of geography states: "[E]verything is related to everything else, but near things are more related than distant things." ${ }^{11}$

A homosexual right is a very classic example to describe this area of legal jurisprudence. Homosexuality or gayism existed from a very early era. The movement to legalize gay marriage was a social call because in 2015 Americans

\footnotetext{
${ }^{29}$ Catherine Mckinnon "Predatory theory"

${ }^{30}$ Daniel Z. Sui, Tobler's First Law of Geography: A Big Idea for a Small World?, 94 ANNALS ASS'N .AM. GEOGRAPHERS 269, 270 (2004).

31 Waldo Tobler, A Computer Movie Simulating Urban Growth in the Detroit Region, 46 ECON. GEOGRAPHY 234, 236 (1970).
} 
were ready to accept same-sex marriage. Lawrence v. Texas, 539 U.S. 558 (2003) ${ }^{32}$ is a historic decision by the United States Supreme Court. The Court struck down the homosexuality law in Texas in a 6- 3 in favour and, by augmentation, negated homosexuality laws in 13 different states, making same-sex sexual action legitimate in each U.S. state and region.

The decision in Obergefell v. Hodges 576 us _ (2015) 33 implied that every one of the fifty states should legitimately perform and perceive the marriage of same-sex couples on an indistinguishable terms and conditions from the marriage of opposite sex couples, with similar rights and obligations.

Morality is not on question here. If brought forward it would raise controversy. However it is seen that such rights of same-sex marriage is not available in Middle Eastern countries or in the Indian subcontinent. Does that mean they do not have homosexuals? Of course they do, but the people living in the society are not ready to accept same-sex marriages because of their religious beliefs, or their mindsets and upbringing. In countries like Bangladesh, Pakistan and India where sex is still considered to be a taboo, homosexual movement would call upon a moral dilemma and probably jail all the gays. In 2009, the Delhi High Court decided in Naz Foundation v. Govt. of NCT of Delhi W.P. (C) 7455/200134 discovered Section 377 and other legitimate prohibitions against private, grown-up, consensual, and non-business same-sex lead to be in direct infringement of basic rights gave by the Indian Constitution. 377: Unnatural offences.--Whoever voluntarily has carnal intercourse against the order of nature with any man, woman or animal, shall be

\footnotetext{
32 LAWRENCE V. TEXAS, 539 U.S. 558 (2003) JUSTIA LAW, https://supreme.justia.com/cases/federal/us/539/558/case.html (last visited Mar 9, 2018)

${ }^{33}$ HOME - SuPREME COURT OF THE UNITED STATES, https:/www.supremecourt.gov/opinions/ (last visited Mar 5, 2018)

${ }^{34}$ HIGH COURTS OF INDIA... HIGH COURTS OF INDIA..., http://lobis.nic.in/ (last visited Mar 6, 2018)
} 
punished with [imprisonment for life], or with imprisonment of either description for a term which may extend to ten years, and shall also be liable to fine. In countries with strict Islamic believes or the followers of Islamic Sharia, homosexuals are punished strictly. In the Washington post it was said that "in Iraq the penal code does not expressly prohibit homosexual acts, but people have been killed by militias and sentenced to death by judges citing sharia law." ${ }^{35}$ It is very questionable that why does an aspect of sociality be so criticized and punished in some parts of the world and so widely accepted in others. This is because of social acceptability. People are not ready religiously, culturally, mentally and physically to accept same sex marriage in the prohibited countries while Americans, Argentine, French and others are. If a law is passed in support of gay marriage in Saudi Arabia, it could actually be questioned as immoral by Saudis and Islamists all over the world as "Quran (7:80-84) - "...For ye practice your lusts on men in preference to women: ye are indeed a people transgressing beyond bounds.... And we rained down on them a shower (of brimstone)" 36 An account that is borrowed from the Biblical story of Sodom. Muslim scholars through the centuries have interpreted the "rain of stones" on the town as meaning that homosexuals should be stoned, since no other reason is given for the people's destruction. (Inexplicably, the story is also repeated in three other suras: 15:74, 27:58 and 29:40)"' 37 However in USA, speaking against LGBT could call the person's morality into question. Therefore it can be said that society varies from geography to geography and so does its cultures. A law might be affected and be depended on the societal acceptance.

\footnotetext{
35 THE STATE OF GAY RIGHTS AROUND THE WORLD WASHINGTON POST, https://www.washingtonpost.com/graphics/world/gay-rights/ (last visited Jan 28, 2018)

${ }^{36}$ AL-QUR'AN AL-KAREEM - القر آن الكريم AL-QUR'AN AL-KAREEM - القرآن الكريم, https:/quran.com/ (last visited Mar 2, 2018)

${ }^{37} \mathrm{http}: / / \mathrm{www}$. thereligionofpeace.com/ (last visited Mar 4, 2018)
} 
Another example to support social acceptability is Polygamy. Area of section 293 of the Criminal Code of Canada unequivocally bans polygamy and debilitates wrongdoers with a five-year imprisonment. Multiple marriages are named as "a serious crime" in Section 290. In countries like Canada a man is expected to have one wife only however, in Middle Eastern countries with Islam as national religion, polygamy is accepted by the society and thus the law is quite varied. Polygamy is prohibited in Tunisia as of Article 18 of the Tunisian law of personal status 1956. Verse 129 of Sura 4 of the Quran states no matter how hard a man strives he cannot treat all co-wives equally. ${ }^{38}$ The traditional approach is to read this verse along with Verse 3 of Sura 4 of the Quran which allows polygamy and demands equal treatment regarding maintenance of willing co-wives. Tunisian reformers held reading the aforementioned two verses together and they prohibit polygamy. However in Syria, Article 17 of The Law of Personal Status says a man may not marry a second wife until it is justified by law and is capable of maintaining the co-wives. ${ }^{39}$ This law tends to be tolerant towards polygamy. Most Middle Eastern countries have imposed restrictions on man willing to marry polygamously. The Algerian Family Law of 1984 was amended in 2005 where Article $\mathcal{8}$ provides that the man requires proving his ability to treat co-wives equally and provide necessities for married life as well as being in possession of the financial capabilities to be able to marry polygamously. ${ }^{40}$ In Iraq the husband must prove that there is some law benefit of the marriage along with the financial capabilities (Law of personal Status 1959). Article 4 of the Muslim Family Ordinance 1961 provides that the man should seek permission from the union council stating why he wants to marry another woman concurrently along with evidencing that his current wife/wives consented; regarding restrictions on

\footnotetext{
${ }^{38}$ MARTIN LAU \& DOREEN HINCHCLIFF, INTRODUCTION TO ISLAMIC LAW (University of London) (2010)p. 67

${ }^{39}$ MARTIN LAU \& DOREEN HINCHCLIFF, INTRODUCTION TO ISLAMIC LAW (University of London) (2010) p. 67

${ }^{40}$ MARTIN LAU \& DoREen HINCHCLIFF, INTROdUCtION TO ISLAMIC LAW (University of London) (2010) p. 68
} 
polygamous marriage restrictions in Bangladesh and Pakistan. In Itwari v Asgari Mr Justice Dhavan held that in India polygamous marriage is tolerated not encouraged. ${ }^{41}$ All these references are very distinguished and vary dramatically according to geography. However they all have the problem in common, polygamy. The law for a common problem varies from country to country is because of its varying social acceptability. People of Islamic nation-states are tolerant towards polygamy given that there are certain restrictions and bindings but if we go 200 years back, polygamy was rather embraced in Islamic countries. As the social perspective and desirability changed along with misuse of the polygamous laws, the laws correspondingly changed because of the society's need or in simpler words "social desirability".

Laws are social requirement, a social need which is required to be in order, up to date and befitting in the society to overcome barriers along with adjudication of problems. Sometimes there are some laws that are available in a country but are hardly followed. For example laws regarding dowry in Bangladesh. The legal system in Bangladesh clearly prohibits providing and receiving dowry in a marriage but this law is hardly followed in the rural areas of the country. This happens because of lack of social awareness in the society of the problem's consequences or in short the society is not ready to accept the law. Here Hart's theory of external point of view could come in handy to define the law to be valid ${ }^{42}$ but that does not change the fact that it is vastly not being followed. Society's mindset regarding dowry first needs to be changed through fear or awareness. A law existing without effectiveness is theoretically a law; practically a law to be a law has to be widely accepted by mass of the society. Why did the law on dowry be introduced? It is because a wide number of cases have come up in the national

\footnotetext{
41 MARTIN LAU \& DOREEN HINCHCLIFF, INTRODUCTION TO ISLAMIC LAW (University of London) (2010) p. 68

42 Herbert lionel Adolphus hart et Al., The concept of law (Oxford University Press) (2012)
} 
courts regarding violence on women that root up to dowry. It is a matter of social necessity that the law be introduced but the society is not ready to accept it, so the society needs to be made aware about it. However the ritual of dowry seems to be fading in the urban areas of Bangladesh which means the society is ready to accept the law while the rural people need nurturing.

\section{Conclusion}

A community or a group of persons, living in any region, who are united by some common bond, is known as society. A society is a group of people related to each other through persistent relations such as social status, roles and social networks. They also share the same geographical territory and subject to the same political authority and dominant cultural expectations. Common bond is some kind of uniformity of factors like nature of the people, habit, custom, beliefs, culture, etc. The societies in this world are versatile. It varies dramatically based on geography. Social norms are not same everywhere. Laws therefore vary geographically because of the social norms and values being different. Law is ever evolving, so is the society, it is just a matter of time when today's major offence might be acceptable in the future. This is all because of our mindsets, i.e. societies' perception. 